\title{
NATURE OF COMBINING ABILITIES AND GENETIC INTERPRETATION FOR SOME QUANTITATIVE TRAITS IN EGYPTIAN COTTON
}

(Received: 26.9.2011)

\author{
By \\ M. D.H. Dewdar \\ Agronomy Department, Faculty of Agriculture, Fayoum University.
}

\begin{abstract}
This investigation was conducted with the objective of approaching an efficient parental choice of cotton cultivars in the breeding program for developing superior cultivars for high yielding and good fiber quality. Five Egyptian cotton genotypes were crossed in a diallel pattern, i.e. in all possible combinations, excluding reciprocals in season 2009. In the summer 2010, field evaluation experiment of 15 entries (5 parents and $10 \mathrm{~F}_{1}$ s) was undertaken. The data revealed that there were noticeable differences between the parental genotypes for their positive significant general combining ability (GCA) effects for most studied traits. In generall, the magnitude of GCA mean squares was mostly greater than SCA mean squares expressed as GCA/SCA ratio, indicated that the magnitude of additive and additive $\mathrm{x}$ additive genetic effects were considerable in the inheritance of all characters rather than non-additive effects, except for boll number, where the effects were mainly non-additive.

The parental genotype Giza $83\left(\mathrm{P}_{4}\right)$ superseded all other parents for GCA effect and showed the highest GCA effects for lint yield and was also in the $2^{\text {nd }}$ rank for seed cotton yield. Giza $81\left(\mathrm{P}_{3}\right)$ had maximum GCA effects for seed cotton yield followed by Giza $85\left(\mathrm{P}_{2}\right)$ for boll number.

Furthermore, Giza $75\left(\mathrm{P}_{1}\right)$ was in the $1^{\text {st }}$ rank by having maximum GCA effects for fiber strength and showed desirable negative GCA effects for fiber fineness, revealing that these parental genotypes could be considered as good combiners in breeding program for developing high yielding genotypes. Out of 10 hybrids, five hybrid combinations, i.e. $\mathrm{P}_{1} \times \mathrm{P}_{2}, \mathrm{P}_{1} \times \mathrm{P}_{3}, \mathrm{P}_{1} \times \mathrm{P}_{4}, \mathrm{P}_{1} \times \mathrm{P}_{5}$ and $\mathrm{P}_{4} \times \mathrm{P}_{5}$ showed desirable specific combining ability and heterotic effects for most of the studied traits.
\end{abstract}

Key words: combining ability, cotton, heterosis, G. barbadense, mean performance.

\section{INTRODUCTION}

Cotton the "white gold" is an important fiber crop and plays vital roles as a cash crop in many countries such as Egypt. Development of a new variety with high yield and fiber quality is the primary objective of all cotton breeders. The need to further amplify efforts for continued genetic improvement of cotton for yield and quality traits in Egypt is even greater today than before in view of a low production per unit area and low fiber quality as compared to other advanced cotton growing countries of the world to meet the challenges of the $21^{\text {st }}$ century.

Breeders of self pollinated crops are primarily interested in combining desirable genes from different genotypes into a single genotype to create variability for a characteristic they wish to improve (Dabholkar, 1992). $\mathrm{F}_{1} \mathrm{~s}$ may exhibit superior performance due to dominance and/or non-allelic interaction. In advanced generations, however, linkage breaks and new combinations are formed. This leads to dissipation of superiority because the degree of dominance observed in the $\mathrm{F}_{1} \mathrm{~S}$ declines and appearance of new recombinations, which showed superiority due to non- allelic interaction.

However, Tang et al. (1993) in cotton reported superior $\mathrm{F}_{2} \mathrm{~S}$ over parents, as they might have a broader range of adaptation than conventional cultivars due to high heterosis. In order to improve productivity, one of the most important steps in a breeding program is the detection of suitable parents. In the current study combining ability analysis (general and specific) was used as a tool to differentiate between good and poor combiners, followed by selection of appropriate crosses. One of the techniques, widely used for this purpose in different crops, including cotton, is diallel analysis (Hayman, 1954 a,b and Dabholkar, 1992). Diallel analysis leads to identification of parents and the appropriate breeding program (Murtaza et al., 2005). 
In cotton, heterosis has a potential of increasing yield from 10-20\% and improving fiber quality. Identification of genetic diversity and GCA effects of parents before crossing reduces the number of crosses to be made and the progenies to be screened and leads to a reduction in cost and time (Kumar, 1999).

Studies of Shakeel et al.(2001) and Ahuja and Dhayal (2007) revealed that seed cotton yield, number of bolls and boll weight were influenced by genes acting non-additively. On the contrary, studies of Ashokkmar et al. (2010) indicated that additive and non- additive gene effects were important for controlling seed cotton yield and number of bolls.

However, Luramge et al. (2007) revealed additive gene effects for fiber strength and micronaire value and non-additive gene action for fiber length. Non-additive gene action for fiber quality traits (fiber length, fiber strength and micronaire reading) have been reported by Hassan et al. (2000) and Preeth and Raveendran (2008). effects for yield contributing parameters and fiber quality of diallel crosses among five different cotton genotypes and to determine appropriate parents and crosses for improving the investigated traits.

\section{MATERIALS AND METHODS}

\subsection{Genetic materials and experimental procedures}

Five long staple genotypes belonging to Egyptian cotton (Gossypium barbadense) germplasm were crossed in a diallel mating design, without reciprocals in season 2009. In the summer 2010, 15 entries (5 parents and $10 \mathrm{~F}_{1}$ 's ) were planted in 25 March, for field evaluation in the Experimental Station, Fac. Agric., Fayoum Univ. The experimental design was randomized complete blocks with three replications. Plot area was one row; 4 x $0.60 \quad \mathrm{~m}$. Restricted randomization was applied where single rows of $F_{1}$ of specific cross combinations were surrounded by its two respective parents. The used parents are presented in (Table 1).

Table (1): Pedigree, origin, year of release and main fiber quality traits of cotton varieties used *

\begin{tabular}{|c|c|c|c|c|c|}
\hline \multirow[b]{2}{*}{ Genotype } & \multirow[b]{2}{*}{ Origin } & \multirow{2}{*}{$\begin{array}{l}\text { Year of } \\
\text { release }\end{array}$} & \multicolumn{3}{|c|}{ Fiber quality traits } \\
\hline & & & $\begin{array}{c}2.5 \% \mathrm{FL} \\
(\mathrm{mm})\end{array}$ & FF $(\mu \mathrm{g} /$ inch $)$ & FS (g/tex) \\
\hline Giza $75\left(\mathrm{P}_{1}\right)$ & Giza 67x Giza 69 & 1975 & 34.00 & 4.50 & 33.00 \\
\hline Giza $85\left(\mathrm{P}_{2}\right)$ & Giza 67 x C.B.58 & 1993 & 30.00 & 4.10 & 29.90 \\
\hline Giza $81\left(\mathrm{P}_{3}\right)$ & Giza 67x (A 5844) & 1983 & 31.40 & 4.20 & 34.70 \\
\hline Giza $83\left(\mathrm{P}_{4}\right)$ & Giza 72x Giza 67 & 1992 & 30.40 & 4.20 & 27.50 \\
\hline Giza $90\left(\mathrm{P}_{5}\right)$ & $\begin{array}{l}\text { Giza } 83 \text { and } \\
\text { Dandara }\end{array}$ & 2000 & 30.80 & 4.20 & 31.20 \\
\hline
\end{tabular}

*Cotton Research Institute , Agric. Res. Center , Ministry of Agric., Giza, Egypt

Recently, a great attention of several investigators has been directed to carefuly study combining abilities and heterotic effects in cotton (Abo El-Zahab and Amein, $2000 \mathrm{a}$ and b, Mosalem et al., 2003, Sorour et al. (2000), Abd El-Hamid and Esmail (2001).

As for Fayoum region, it is known that the obsolete varieties; Giza 75, Giza 85, Giza 81 and Giza 83 were cultivated since 1975 and replaced by Giza 90 in the current time. However, most of the obsolete varieties proved to be good combiners as judged by their ability to transmit high yield to their progenies and were employed in crosses to develop new promising cotton varieties.

The purposes of this research were to estimate the amount of heterosis and the GCA and SCA

\subsection{Characters measured}

Ten individual random guarded plants from each plot were monitored and tagged to collect data. The studied traits were; seed cotton yield per plant (SCY, g), lint yield per plant (LY, g), boll number per plant $(\mathrm{BN})$, boll weight $(\mathrm{BW}, \mathrm{g})$, ginning outturn (GOT, \%), fiber length (FL, mm), fiber strength (FS, g/tex) and fiber fineness (FF, $\mu \mathrm{g} /$ inch).

After the harvest, seed cotton samples were ginned on a mini-laboratory roller-gin for measuring lint percentage and fiber quality. Fiber samples were analyzed for fiber quality properties by High Volume Instrument (HVI).

\subsection{Statistical manipulation of the data}

General (GCA) and specific (SCA) combining abilities were computed according to Griffing's 
method 2 (parents and one set of $F_{1}$ 's are included but not reciprocals, i.e. $\{\mathrm{P}(\mathrm{P}+1) / 2\}$ combinations, model 1 (fixed effects). Forms of analysis given by Griffing (1956) and Singh and Chaudhary (1979) were applied. Magnitude of heterosis in terms of percentage of increase (+) or decrease (-) of $F_{1}$ over mid parents (MP) for each character was calculated (Falconer, 1981).

\section{RESULTS AND DISCUSSION \\ 3.1. Analysis of variance}

The analysis of variance exerted significant differences among entries for each trait (Table 2) among parents $(\mathrm{P}), \mathrm{F}_{1}$ crosses $(\mathrm{C})$, genotypes $(\mathrm{G})$ and $\mathrm{P}$ vs $\mathrm{C}$ for cotton yield, its components and fiber quality traits. The significant variation among parents indicated that the data are reliable for further analysis by diallel mating procedure as suggested by Griffing (1956). The mean squares of general and specific combining ability for most studied yield and fiber quality traits were significant and highly significant in $\mathrm{F}_{1}$ generation.

The magnitude of the GCA/ SCA ratios indicated that additive gene effects were more important in controlling all traits, except boll number, where the effects were non-additive (Table 2). These results agreed with those obtained by Ashokkmar et al. (2010), Khan et al. (2011) and Lu and Myers (2011).

\subsection{Combining abilities}

Estimates of general and specific combining ability effects for the five cotton varieties and their hybrids in yield, its component and fiber quality traits are shown in Table (3). The results showed high positive GCA and SCA effects in the studied traits. These findings indicated that the parental genotype Giza $83\left(\mathrm{P}_{4}\right)$ superseded all other parents for GCA and showed the highest GCA effects for lint yield and was also in the $2^{\text {nd }}$ rank in GCA effects for seed cotton yield.

The genotype Giza $81\left(\mathrm{P}_{3}\right)$ had maximum GCA effects for seed cotton yield followed by Giza 85 $\left(\mathrm{P}_{2}\right)$ for boll number. While, Giza $75\left(\mathrm{P}_{1}\right)$ was in the $1^{\text {st }}$ rank by having maximum GCA effects for fiber strength and showed desirable negative GCA for fiber fineness.

Moreover, Giza $85\left(\mathrm{P}_{2}\right)$ and Giza $90\left(\mathrm{P}_{5}\right)$ showed desirable GCA effects in some cases, revealing that these varieties could be considered as good combiners in breeding programs for developing high yielding and fiber quality genotypes. While, the other parental genotypes showed negative GCA effects and could be considered as poor combiners for most studied traits.
Significant or highly significant positive SCA effects were obtained for seed cotton yield per plant by the crosses; $\mathrm{P}_{1} \times \mathrm{P}_{2}, \mathrm{P}_{1} \times \mathrm{P}_{4}, \mathrm{P}_{2} \times \mathrm{P}_{3}, \mathrm{P}_{3} \times$ $\mathrm{P}_{5}$ and $\mathrm{P}_{4} \times \mathrm{P}_{5}$. Furthermore, desirable SCA effects for lint yield were exerted by four crosses; $\mathrm{P}_{2} \times \mathrm{P}_{4}$, $\mathrm{P}_{2} \times \mathrm{P}_{5}, \mathrm{P}_{3} \times \mathrm{P}_{4}$ and $\mathrm{P}_{4} \times \mathrm{P}_{5}$.

The cross combination $\mathrm{P}_{1} \times \mathrm{P}_{4}$ was the best in SCA effects for SCY, while for LY the cross $\mathrm{P}_{2} \mathrm{X}$ $\mathrm{P}_{5}$ was the best. Concerning fiber length trait, estimates of SCA effects were significant or highly significant for the three hybrids; $\mathrm{P}_{1} \times \mathrm{P}_{2}, \mathrm{P}_{1}$ x $\mathrm{P}_{3}$ and $\mathrm{P}_{1} \times \mathrm{P}_{4}$. While, for fiber strength, the pronounced SCA effects were detected by the two crosses $\mathrm{P}_{1} \times \mathrm{P}_{3}$ and $\mathrm{P}_{3} \times \mathrm{P}_{4}$.

In the meantime, desirable negative SCA effects for fiber fineness were exerted by three crosses; $\mathrm{P}_{1} \times \mathrm{P}_{2}, \mathrm{P}_{1} \times \mathrm{P}_{4}$ and $\mathrm{P}_{1} \times \mathrm{P}_{5}$. Out of 10 hybrids, five hybrid combinations; i.e. $\mathrm{P}_{1} \times \mathrm{P}_{2}, \mathrm{P}_{1} \mathrm{x}$ $\mathrm{P}_{3}, \mathrm{P}_{1} \times \mathrm{P}_{4}, \mathrm{P}_{1} \times \mathrm{P}_{5}$ and $\mathrm{P}_{4} \times \mathrm{P}_{5}$ showed desirable specific combining ability effects for most studied yield and fiber quality traits .

These findings confirm the data obtained in Table (4) which showed the magnitude of heterosis effects. This indicates the presence of allelic interaction.

It is worthy to mention that high $\mathrm{x}$ low, low $\mathrm{x}$ high and in some cases high $\mathrm{x}$ high GCA parents performed well in $\mathrm{F}_{1}$ of high SCA effects and reveal also the best mean performance. Similar results were noted by Shakeel et al. (2001), Ahuja and Dhayal (2007), Luramage et al. (2007) Preeth and Raveendran (2008) and Ashokkmar et al. (2010).

\subsection{Heterosis}

The cross $\mathrm{P}_{4} \times \mathrm{P}_{5}$ showed highly significant positive and negative heterosis for SCY, LY, BN, GOT and FF traits with estimated values of 13.14, $38.28,20.84,21.12$, and $8.23 \%$, respectively. However, the three crosses; $\mathrm{P}_{1} \times \mathrm{P}_{3}, \mathrm{P}_{1} \times \mathrm{P}_{5}$ and $\mathrm{P}_{2}$ $\mathrm{xP}_{4}$ also showed highly significant positive heterotic effects for boll weight ,fiber length and fiber strength (Table 4). These findings confirm the data obtained in Table (3) which showed the magnitude of SCA effects. This indicates the presence of allelic interaction. Similar results were noted by Pavasia et al. (1999) ,Sorour et al. (2000), Abdel-Hamid and Esmail (2001) and Rauf et al. (2005).

\subsection{Mean performance of genotypes}

Mean performances of the five parental varieties and their hybrid combinations for yield, its components and fiber quality traits are presented in (Table 5). The variety Giza $75\left(\mathrm{P}_{1}\right)$ showed the highest seed and lint yields, ginning outturn and fiber fineness traits. Also, the variety 
Table (2) : Analysis of variance showing mean squares for yield, its components and fiber quality traits in Egyptian cotton.

\begin{tabular}{|c|c|c|c|c|c|c|c|c|}
\hline S.O.V. & SCY & LY & BN & BW & GOT & FL & FS & FF \\
\hline Genotypes (G) & $8.30^{* *}$ & $6.50^{* *}$ & $4.90^{* *}$ & $0.21^{*}$ & $0.04^{* *}$ & $9.25^{* *}$ & $11.21^{* *}$ & $1.11^{* *}$ \\
\hline Parents (P) & $9.67^{* *}$ & $2.80^{*}$ & $3.95^{*}$ & 0.10 & 0.01 & $7.31^{* *}$ & $9.35^{* *}$ & $0.90^{*}$ \\
\hline Crosses (C) & $7.40^{* *}$ & $8.00^{* *}$ & $8.14^{* *}$ & 0.17 & $0.06^{* *}$ & $6.60^{* *}$ & $8.47^{* *}$ & $0.87^{*}$ \\
\hline P vs C & $30.23^{* *}$ & $23.57^{* *}$ & $11.12^{* *}$ & 0.07 & 0.11 & $5.42^{* *}$ & $6.50^{*}$ & 0.79 \\
\hline GCA & $20.41^{* *}$ & $8.50^{* *}$ & $5.16^{* *}$ & 0.14 & $0.06^{*}$ & $3.51^{* *}$ & $4.36^{* *}$ & $0.91^{*}$ \\
\hline SCA & $6.31^{* *}$ & $6.41^{* *}$ & $5.84^{* *}$ & 0.09 & $0.05^{*}$ & $1.91^{*}$ & $3.71^{* *}$ & $0.85^{*}$ \\
\hline Pooled error & 0.39 & 0.30 & 0.36 & 0.05 & 0.02 & 0.25 & 0.28 & 0.17 \\
\hline GCA/SCA & 3.23 & 1.32 & 0.88 & 1.55 & 1.20 & 1.83 & 1.17 & 2.60 \\
\hline
\end{tabular}

$*, * *$ Significance at $\%$ and $1 \%$ levels .

Table (3): General and specific combining ability effects for yield, its components and fiber quality traits of five parents and their ten $F_{1}$ 's in Egyptian cotton.

\begin{tabular}{|c|c|c|c|c|c|c|c|c|}
\hline Genotypes & SCY & LY & BN & BW & GOT & FL & FS & FF \\
\hline P1 & $0.450^{* *}$ & $-0.390^{* *}$ & $0.370^{*}$ & $-0.400^{* *}$ & $0119^{* *}$ & 0.009 & $0.317^{* *}$ & -0.341 \\
\hline P2 & $0.730^{* *}$ & -0.223 & $0.920^{* *}$ & $0.265^{* *}$ & $0.112^{* *}$ & $0.123^{* *}$ & -0.005 & -0.116 \\
\hline P3 & $0.950^{* *}$ & $-0.517^{* *}$ & $-0.410^{* *}$ & $-0.175^{* *}$ & -0.012 & $0.116^{* *}$ & -0.038 & 0.318 \\
\hline P4 & $0.832^{* *}$ & $1.130^{* *}$ & $0.731^{* *}$ & $-0.161^{*}$ & $0.120^{* *}$ & $0.110^{* *}$ & $-0.131^{* *}$ & 0.410 \\
\hline P5 & $-0.390^{* *}$ & $0.240^{*}$ & 0.260 & -0.101 & $0.111^{* *}$ & $0.112^{* *}$ & 0.001 & 0.219 \\
\hline P1 x P2 & $0.881^{* *}$ & -0.253 & 0.620 & 0.051 & $0.115^{* *}$ & $0.113^{* *}$ & $-0.291^{*}$ & -0.710 \\
\hline P1 x P3 & 0.170 & 0.516 & $0.980^{* *}$ & 0.192 & 0.016 & $0.118^{* *}$ & $0.821^{* *}$ & 0.360 \\
\hline P1 x P4 & $2.210^{* *}$ & 0.245 & 0.491 & 0.032 & -0.012 & $0.032^{*}$ & -0.032 & -0.420 \\
\hline P1 x P5 & $3.340^{* *}$ & $-0.712^{*}$ & -0.301 & 0.170 & $-0.045^{* *}$ & 0.009 & $0.401^{* *}$ & -0.900 \\
\hline P2 x P3 & $0.501^{*}$ & $-0.612^{*}$ & -0.562 & -0.071 & -0.031 & 0.016 & 0.003 & 0.811 \\
\hline P2 x P4 & 0.340 & $1.231^{* *}$ & $-1.312^{* *}$ & $0.316^{* *}$ & $-0.037^{*}$ & 0.014 & 0.200 & 0.690 \\
\hline P2 x P5 & $-0.811^{*}$ & $1.980^{* *}$ & $-1.130^{* *}$ & 0.220 & $0.085^{* *}$ & 0.008 & 0.195 & $2.110^{* *}$ \\
\hline P3 x P4 & -0.471 & $1.856^{* *}$ & 0.617 & -0.212 & $0.761^{* *}$ & 0.101 & $0.690^{* *}$ & $1.601^{* *}$ \\
\hline P3 x P5 & $1.610^{* *}$ & 0.231 & 0.556 & 0.101 & -0.031 & 0.014 & $0.390^{*}$ & 0.400 \\
\hline P4 x P5 & $1.230^{* *}$ & $1.120^{* *}$ & $1.890^{* *}$ & $-0.318^{* *}$ & 0.019 & 0.108 & $0.315^{*}$ & 0.053 \\
\hline
\end{tabular}

$\mathrm{G}_{\mathrm{i}}$ and $\mathrm{S}_{\mathrm{ij}}$ denote general and specific combining ability effects. 
Table (4): Percentage of heterosis over the mid-parent (MP\%) for yield, its components and fiber quality traits in Egyptian cotton.

\begin{tabular}{|c|c|c|c|c|c|c|c|c|}
\hline Genotypes & SCY & LY & BN & BW & GOT & FL & FS & FF \\
\hline P1 x P2 & $6.38^{* *}$ & $16.40^{* *}$ & $3.78^{* *}$ & $0.80^{* *}$ & $8.10^{* *}$ & $3.65^{* *}$ & -0.37 & $11.68^{* *}$ \\
\hline P1 x P3 & $-1.34^{*}$ & $4.29^{* *}$ & $7.84^{* *}$ & $21.51^{* *}$ & $5.26^{* *}$ & $5.92^{* *}$ & $6.24^{* *}$ & $-0.96^{* *}$ \\
\hline P1 x P4 & $6.36^{* *}$ & $4.67^{* *}$ & $9.14^{* *}$ & $9.73^{* *}$ & -1.35 & $-1.83^{* *}$ & $10.96^{* *}$ & $-6.26^{* *}$ \\
\hline P1 x P5 & $11.98^{* *}$ & $-1.55^{* *}$ & $2.79^{* *}$ & $13.43^{* *}$ & $-13.5^{* *}$ & $2.79^{* *}$ & $9.02^{* *}$ & $-14.63^{* *}$ \\
\hline P2 x P3 & $4.34 * *$ & 0.74 & $9.80^{* *}$ & $-5.51^{* *}$ & -2.77 & $2.02^{* *}$ & $2.50^{* *}$ & $2.56^{* *}$ \\
\hline P2 x P4 & $3.52^{* *}$ & $6.80^{* *}$ & $-3.44^{* *}$ & $9.05^{* *}$ & 1.40 & $2.18^{* *}$ & $5.13^{* *}$ & $1.75^{* *}$ \\
\hline P2 x P5 & 0.17 & $26.11^{* *}$ & $4.06^{* *}$ & $0.81^{* *}$ & $20.00^{* *}$ & $-4.20^{* *}$ & $-6.97 * *$ & $-8.10^{* *}$ \\
\hline P3 x P4 & $6.45^{* *}$ & $25.52^{* *}$ & $10.11^{* *}$ & $-9.48^{* *}$ & $16.21^{* *}$ & $3.44^{* *}$ & $-7.21^{* *}$ & $7.14^{* *}$ \\
\hline P3 x P5 & $11.04 * *$ & $17.18^{* *}$ & 3.96 & $-6.77^{* *}$ & $4.10^{* *}$ & $3.28^{* *}$ & $-3.00^{* *}$ & $6.02^{* *}$ \\
\hline P4 x P5 & $13.14^{* *}$ & $38.28^{* *}$ & $20.84^{* *}$ & $-6.60^{* *}$ & $21.12^{* *}$ & $-3.15^{* *}$ & $2.45^{* *}$ & $-8.23^{* *}$ \\
\hline
\end{tabular}

and ** indicate significance at 0.05 and 0.01 probability levels, respectively.

Table (5): Mean performances of parental genotypes and their crosses for yield, its component and fiber quality traits in Egyptian cotton.

\begin{tabular}{|c|c|c|c|c|c|c|c|c|}
\hline Genotypes & SCY & LY & BN & BW & GOT & FL & FS & FF \\
\hline P1 & 34.20 & 13.23 & 13.66 & 2.31 & 0.39 & 32.17 & 27.23 & 4.00 \\
\hline P2 & 35.60 & 12.37 & 13.33 & 2.66 & 0.35 & 31.25 & 31.00 & 3.70 \\
\hline P3 & 31.69 & 11.90 & 14.00 & 2.43 & 0.38 & 30.89 & 33.00 & 4.10 \\
\hline P4 & 33.69 & 12.00 & 15.67 & 2.21 & 0.36 & 31.00 & 34.06 & 4.30 \\
\hline P5 & 31.89 & 11.15 & 14.22 & 2.30 & 0.35 & 33.01 & 33.50 & 4.20 \\
\hline P1 x P2 & 37.13 & 14.90 & 14.00 & 2.50 & 0.40 & 32.87 & 29.00 & 4.30 \\
\hline P1 x P3 & 32.50 & 13.10 & 15.00 & 2.88 & 0.40 & 32.00 & 32.00 & 4.01 \\
\hline P1 x P4 & 36.10 & 13.20 & 16.00 & 2.48 & 0.37 & 31.00 & 34.60 & 3.89 \\
\hline P1 x P5 & 37.00 & 12.00 & 14.33 & 2.61 & 0.32 & 33.50 & 33.10 & 3.50 \\
\hline P2 x P3 & 35.10 & 12.22 & 15.00 & 2.40 & 0.35 & 31.70 & 32.80 & 4.00 \\
\hline P2 x P4 & 35.86 & 13.00 & 14.00 & 2.65 & 0.36 & 31.80 & 34.20 & 4.07 \\
\hline P2 x P5 & 33.80 & 14.10 & 14.33 & 2.50 & 0.42 & 30.78 & 30.00 & 3.63 \\
\hline P3 x P4 & 34.80 & 15.00 & 16.33 & 2.10 & 0.43 & 32.02 & 31.11 & 4.50 \\
\hline P3 x P5 & 35.30 & 13.50 & 14.67 & 2.20 & 0.38 & 33.00 & 32.25 & 4.40 \\
\hline P4 x P5 & 37.10 & 16.00 & 18.00 & 2.10 & 0.43 & 31.00 & 34.61 & 3.90 \\
\hline LSD 5\% & 1.10 & 0.89 & 1.50 & 0.20 & 0.03 & 0.87 & 1.24 & 0.36 \\
\hline LSD 1\% & 1.40 & 1.13 & 1.86 & 0.36 & 0.04 & 1.02 & 1.70 & 0.51 \\
\hline
\end{tabular}


Giza $90\left(\mathrm{P}_{5}\right)$ showed the highest means of fiber length and strength traits, while the genotypes Giza $83\left(\mathrm{P}_{4}\right)$ and Giza $85\left(\mathrm{P}_{2}\right)$ were the highest performing for boll number and boll weight, respectively.

The high means of the tested genotypes were transmitted to most of their hybrids. While, the lowest means were shown by Giza $81\left(\mathrm{P}_{3}\right)$ for SCY, Giza $90\left(\mathrm{P}_{5}\right)$ for LY and GOT, Giza $85\left(\mathrm{P}_{2}\right)$ for BN, $\left(\mathrm{P}_{4}\right)$ for BW, FL and FF and Giza $75\left(\mathrm{P}_{1}\right)$ for FS.

Four hybrids; $\mathrm{P}_{1} \times \mathrm{P}_{2}, \mathrm{P}_{1} \times \mathrm{P}_{4}, \mathrm{P}_{1} \times \mathrm{P}_{5}$ and $\mathrm{P}_{4} \times$ $P_{5}$ showed the values of $37.13,36.10,37.00$ and $37.10(\mathrm{~g})$ for only SCY/P trait, respectively.

The performance of the $F_{1}$ hybrids showed higher values for $L Y$ than their parents for three crosses; $\mathrm{P}_{1} \times \mathrm{P}_{2}, \mathrm{P}_{3} \times \mathrm{P}_{4}$ and $\mathrm{P}_{4} \times \mathrm{P}_{5}$ where the values were $14.90,15.00$ and $16.00(\mathrm{~g})$. The performance of the $F_{1}$ hybrids showed higher values than their respective parents for the crosses; $\mathrm{P}_{1} \times \mathrm{P}_{4}, \mathrm{P}_{2} \times \mathrm{P}_{3}, \mathrm{P}_{3} \times \mathrm{P}_{4}$ and $\mathrm{P}_{4} \times \mathrm{P}_{5}$ for $\mathrm{BN}$ where the highest values were expressed by the cross $\mathrm{P}_{4} \times \mathrm{P}_{5}$ (18.00).

The mean values for the tested crosses ranged from 2.1 to $2.88(\mathrm{~g})$ for boll weight, 32 to $43 \%$ for ginning outturn, 30.78 to 33.50 (mm) for fiber length, 29.00 to $34.61(\mathrm{~g} / \mathrm{tex})$ for fiber strength and 3.5 to 4.5 ( $\mu \mathrm{g} / \mathrm{inch}$ ) for fiber fineness. These results are in general agreement with those obtained by Abo El-Zahab and Amein (2000 a and b) and El-Adl et al. (2001) working on Egyptian cotton varieties.

It may be concluded that the four parents, i.e. $\mathrm{P}_{4}$ (Giza 83 ), $\mathrm{P}_{3}$ (Giza 81), $\mathrm{P}_{2}$ (Giza 85) and $\mathrm{P}_{1}$ (Giza 75), besides five hybrids, i.e. $\mathrm{P}_{1} \times \mathrm{P}_{2}, \mathrm{P}_{1} \times \mathrm{P}_{3}, \mathrm{P}_{1} \mathrm{x}$ $\mathrm{P}_{4}, \mathrm{P}_{1} \times \mathrm{P}_{5}$ and $\mathrm{P}_{4} \times \mathrm{P}_{5}$ (as a source of high yielding genes to enrich the gene pool) may be incorporated in multiple crosses system followed by pedigree selection for obtaining high yielding and good fiber quality lines.

\section{REFERENCES}

Abdel-Hamid A.A. and Esmail R.M. (2001). Breeding cotton for water stress condition. 2-Fiber properties . Annals Agric. Sci., Ain Shams Univ. Cairo, 46(1):156-188.

Abo El-Zahab A.A. and Amein M.M.M. (2000 a). Prospective for breeding short season cotton. 1-Combining ability for cotton yield and its contributing variables. Proc. $9^{\text {th }}$ Conf. Agron. Minufiya Univ. 1-2 Sept. 305329.

Abo El-Zahab A.A. and Amein M.M.M. (2000 b). Prospective for breeding short season cotton. 3-Tolerance to late planting stress.
Proc. $9^{\text {th }}$ Conf. Agron. Minufiya Univ. 1-2 Sept.345-368.

Ahuja S.L.and Dhayal L.S. (2007). Combining ability in $4 \times 13$ line $x$ tester crosses of Gossypium hirsutum. Euphytica, 153: 8798.

Ashokkumar K., Ravikesavan R. and Prience K.S.J. (2010). Combining ability estimates for yield and fiber quality traits of upland cotton (Gossypium hirsutum). Inter. J. Agric. Biol. 2(1): 179-189.

Dabholkar A.R. (1992). Elements of Biometrical Genetics. Concept Publ. Camp., New Delhi, India.

El-Adl A.M., El-Diasty Z.M., Awad A.A., Zeina A.M. and Abd El- Bary A.M. (2001). Inheritance of quantitative traits of Egyptian cotton. (G.barbadense L.). A-Yield and yield component traits . Egypt . J. Agric. Res., 79 (2): 625-646.

Falconer D.S. (1981). Introduction to quantitative genetics, Longman, New- York. pp.340.

Griffing B. (1956). Concept of general and specific combining ability in relation to diallel crossing system Austr. J. Biol. Sci. 9: 463-493.

Hassan G., Mohamed G. and Razzaq A. (2000). Combining ability and estimates in a diallel cross of cotton. Sarhad Journal of Agric. 15: 563-568.

Hayman B.I. (1954a). The analysis of variance of diallel crosses. Genetics, 39: 789-809.

Hayman B.I. (1954b). The analysis of variance of diallel tables. Biometrics, 10: 235-244.

Khan S.A., Khan N., Mohammed F., Ahmad M., Khan I., Bibi Z. and Khan I.U. (2011). Combinibg ability analysis in interspecfic F1 diallel cross of upland cotton. Pak. J.Bot. 43 (3): 1719-1723.

Kumar L.S. (1999). DNA markers in plant improvement. An overview. Biotechnology Advances, 17: 143-182.

Lu H. and Myers G.O. (2011). Combining abilities and inheritance of yield in influential upland cotton varieties. Austr. I. of Crop Sci., 5(4): 384-390.

Luramage E. P., Labuschagne M.T. and Herselman L. (2007). Combining ability for yield and fiber characteristics in Tanzaian cotton germplasm. Euphytica, 161: 383389.

Mosalem M.E., Sorour F.A., Omar A.M., Awad A. A. and El - Akhdar A. A. A. (2003). Evaluation of some cotton crosses for earliness and economical traits. Proc. $10^{\text {th }}$ 
Conf. Agron. Suez Canal Univ. 7-10 Oct.

Murtaza N., Kitaoka M. and Ali G.M. (2005). Genetic differentiation of cotton cultivars by polyacrylamide gel electrophoresis. J.Cen. Eur. Agric. 6: 69-76.

Pavasia M.J., Shukla P.T. and Patel U.G. (1999). Combining ability analysis over environments for fiber characters in Upland cotton . Indian J. Genet . 59 (1) : 77-81.

Preeth S. and Raveendran T.S. (2008). Combining ability and heterosis for yield and fiber quality traits in line $\mathrm{x}$ tester crosses of upland cotton $(G$. hirsutum L.). Inter. J. of Plant Breed. and Genet.2 (2): 64-74.

Rauf S., Khan T.M. and Nazir S. (2005). Combining ability and heterosis in Gossypium hirsutum L. Inter. J. Agric. Biol. 7 (1): 109-113.

Shakeel A., Khan I.A. and Azha F. M. (2001).
Study pertaining to the estimation of gene action controlling yield and related traits in upland cotton. Journal of Biologigal Science, 1: 67-70.

Singh R. K. and Chaudhary B.D. (1979). Biometrical Methods in Quantitative Genetic Analysis. Ludhiana, New Delhi, India .

Sorour F.A., Mosalem M.E., Awad and A. A. , Soliman Y.A. (2000). Studies on some economic characters in some cotton crosses. 2- Yield, yield components and fiber properties. Proc. $9^{\text {th }}$ Conf. Agron. Minufiya Univ. 1-2 Sept. 295-304.

Tang B., Jenkins J.N., McCarty J.C. and Watson C.E. (1993). $F_{2}$ hybrids of host plant germplasm and cotton cultivars: Heterosis and combining ability for lint and yield components. Crop Sci., 33:700-705.

\title{
طبيعة القدرات الإتتلافية والتفسير الوراثى لبعض الصفات الكمية فى القطن المصرى
}

\author{
محمد دسوقى حسن دويدار \\ قسم المحاصيل - كلية الزراعة - جامعة الفيوم
}

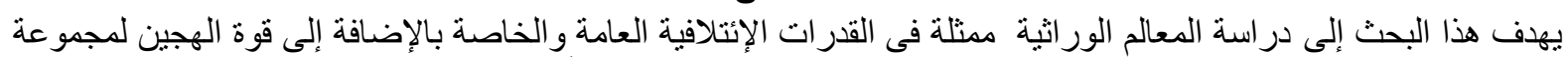

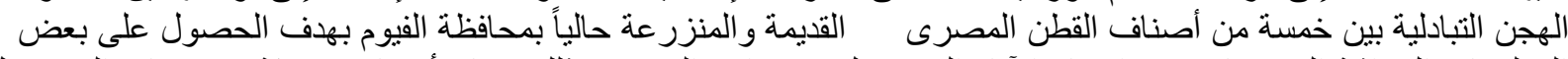
المعلومات الور اثية التى تساعد عند اختبار الآباء التى تدخل فى برامج الته التهجين وذللك لإنتاج أصناف منفوقة فى صفات المحصول

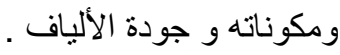

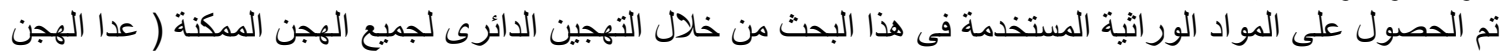

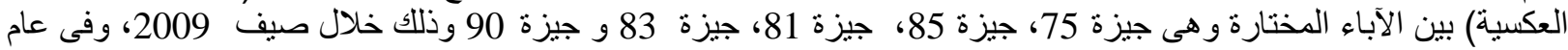

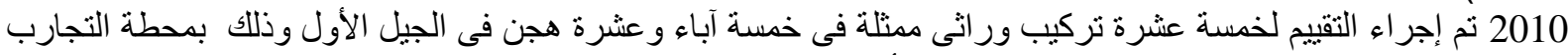

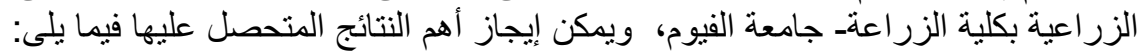

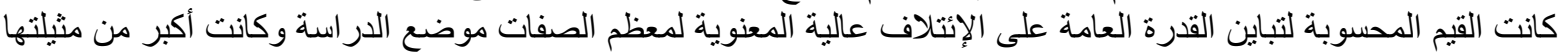

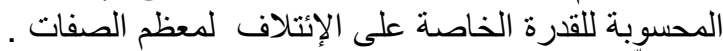

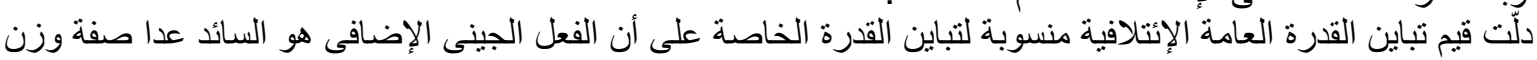
اللوزة حيث كان الفعل غير الإضافى هو العامة الإنتائد.

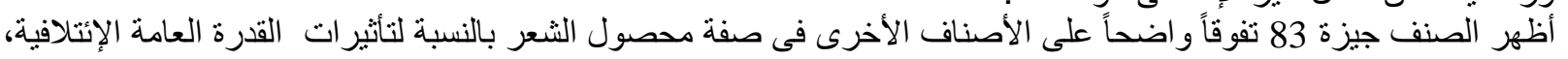

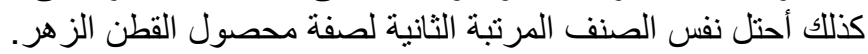

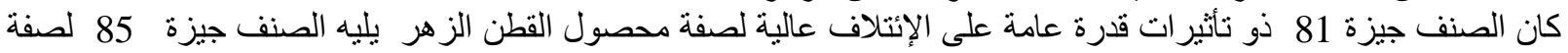

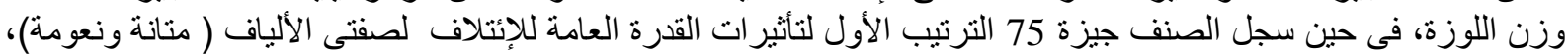
و التى تعكس تأثير الفعل الجينى المضيف و أن هذه الأصناف معطية من صفاتها لأنسالها و التى يمكن إستخدامها في بل بر امج نربية القطن.

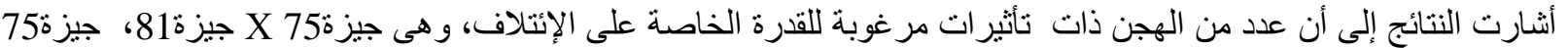

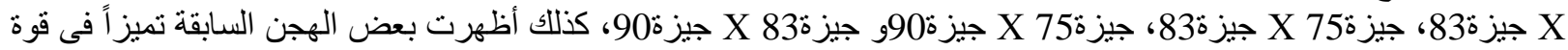
الهجين لبعض الصفات.

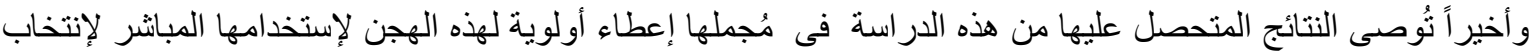

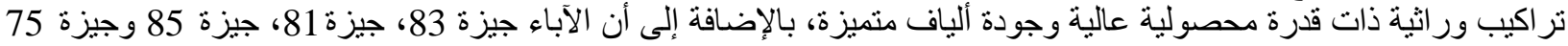

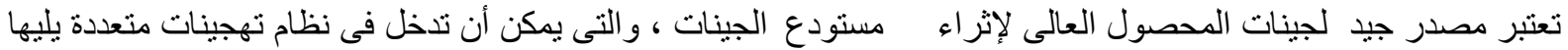

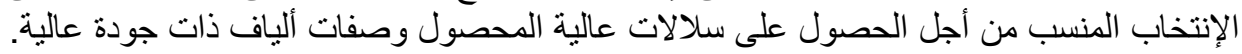

المجلة العلمية لكلية الزراعة - جامعة القاهرة - المجلد (62) العدد اللابع ( أكتوبر 